\title{
Managerial aspect of shipbuilding through HBOR export credit insurance operations
}

\section{Upravljački aspekt sektora brodogradnje kroz poslove osiguranja izvoza HBOR-a}

Asst. prof.Martina Sopta, PhD

Faculty of Economics and Business, University of Zagreb

E-mail:msopta@efzg.hr

\section{Lucija Šola, mag. oec}

Croatian Bank for Reconstruction and Development

E-mail: lucija.sola@outlook.com

\section{Doc.dr.sc. Martina Sopta}

Ekonomski fakultet Sveučilišta u Zagrebu E-mail:msopta@efzg.hr

\section{Lucija Šola, mag. oec}

Hrvatska banka za obnovu i razvoj

E-mail: lucija.sola@outlook.com dogradnje: financijska potpora, restrukturiranje, privatizacija i osiguranje izvoza. Osiguranje izvoza ima velik utjecaj na oporavak domaće brodogradnje uzme li se u obzir prisutnost visokog stupnja rizika u izvozu. Temeljni cilj osiguranja izvoza je povećanje konkurentnosti hrvatskih brodogradilišta u inozemstvu.

\section{Introduction}

The shipbuilding industry is of high importance and interest for Croatia since it provides many jobs for employees in professions with a shortage of workers. For decades, Croatian shipbuilding managerial economics was based on financial aid provided by 
Sopta, M., Šola, L.

Managerial aspect of shipbuilding through HBOR export credit insurance operations the government. The aim of this paper is to answer the following questions: how have models of managerial economics influenced the Croatian shipbuilding industry recovery, what are their fundamental goals, what are the forces the world's leading shipbuilding countries base their progress on, and what impact has the export credit insurance of HBOR had on the shipbuilding industry recovery? Answers to these questions will give a better insight into the role that the export credit insurance business of HBOR holds in the Croatian economy.

For the purposes of this paper, the literature of domestic and foreign authors in the field of managerial economics, international economics, shipbuilding and international market regulation (scientific papers and journals as well as official websites) was used. The literature review results were synthesized and used as a foundation for data analysis. Methods used in this research include the historical method, comparative method, inductive and deductive methods. The topic is generally poorly researched by the scientific community in Croatia, therefore, sources of literature are limited. For the purposes of export credit insurance business analysis, the latest data collected from the secondary sources were analyzed, including internal database and reports owned by the HBOR.

Content and structure of the paper are presented in five chapters. The Introduction defines the problem, subject matter and the aim of the research, as well as the motive for undertaking this market research. The second chapter explains basic theoretical concepts and development of the shipbuilding management in national and international economics. The third chapter presents the characteristics of export credit insurance from theoretical and regulatory points of view while the fourth part presents the analysis of the HBOR's export credit insurance business. The final chapter is the conclusion.

\section{Shipbuilding managerial economics}

\subsection{Shipbuilding models and theories in the scope of managerial economics}

Managerial economics deals with economic methods and techniques for solving different business problems, or in other words, it determines the best way to achieve specific goals of the observed system in a given environment. (Rupčić, 2016). Managerial economics, as well as prosperity economics, industrial economics, and regulatory economics, are parts of the microeconomics. Modern managerial economics provides correct and effective decision-making concepts and less operational procedures, techniques, and decision-making tools on specific business issues. Managerial economics uses models and theories for content processing, prediction and exploration. The model is a simplified image of a reality segment. We often use facts or phenomena as variables and try to explore the relationship between them and some other variables. On the other hand, a theory is a model with the specification of empirical variables and facts that are subject to change which we try to predict. Without the theory, changes could not be explained or predicted. Managerial economics of Croatian shipbuilding will be explained through currently used models and theories.

Shipbuilding is a traditionally important industry for the following counties: the County of Istria, the County of Primorje-Gorski Kotar, and the County of Split-Dalmatia. According to Bazina (2016), in 2016 there were 259 companies registered in the shipbuilding industry in Croatia. They have employed nearly 11.000 workers and their total turnover was almost HRK 2 billion. The five largest shipyards are "Brodosplit d.d.," "Brodotrogir d.d.,"Uljanik d.d.," "Viktor Lenac d.d., and "Brodograđevna industrija 3. Maj d.d.". Combined, they employ around 8.000 workers (Bazina, 2016). In terms of deadweight tonnage (hereafter DWT) in the World Order Book, in July 2017, Croatia was ranked in the 9th place (behind China, Japan, South Korea, the Philippines, Vietnam, Brazil, Taiwan, and Spain). The leading country was China (with $42 \%$ of the total market), followed by Japan (26\% of the market) and South Korea (24\% of the market). In the first half of 2017, Croatia accounted for around $0.35 \%$ of the world vessel production and $21 \%$ of the European vessel production (Hrvatska brodogradnja - Jadranbrod, 2017a).

Managerial economics of Croatian shipbuilding is based on the government influence that has, since the independence, always provided significant financial aid regardless how extremely low the added value was. This was due to the fact that large 
Croatian shipyards have been in State's majority or exclusive ownership until recently (Bendeković and Vuletić, 2011).Additionally, the shipbuilding industry is a strategically important economic branch and it is of a great national and regional significance. In case of the collapse of the shipbuilding industry, Croatia would lose $12 \%$ to $15 \%$ of annual export revenues, HRK 1.29 billion of tax revenues, and about 11.000 jobs (Bendeković and Vuletić, 2011). Increased focus on innovation, research and development, and sustainable development of the industry are current trends in the world of shipbuilding, while the workforce is losing its importance. Shipbuilding is a strategically important industry in Croatia due to its multiplier effect on the national economy and the economy of the region in which the industrial activity is taking place (Žužul, 2016).A positive impact of the shipbuilding is also reflected through the construction of coastal infrastructure that attracts foreign and domestic investments and improves the living standard of the local population, as well as the region's image. The shipbuilding industry provides a wide range of professions with employees ranging from unskilled workers to highly educated professionals for both shipbuilding and related industries such as metal industry, wood industry, paint and varnish industry, and others.

Development and maintenance of the shipbuilding industry have a significant impact on employment in Croatia and it became a social and a political issue. It is estimated that one job in the shipyards creates three to five additional jobs in the related industries in the county. Industry multiplier is higher in countries with a developed shipbuilding suppliers industry. A low multiplier indicates a high import dependency and results in lower benefits for the national economy (Sokolić, 2008). However, the shipbuilding industry is generally characterized by low profitability, long business cycles, capital intensity and high debt ratios (Žužul, 2016). Many of the current Croatian shipbuilding problems arise from the Homeland War period. During the war, shipyards, which used to be reliable partners to buyers, have lost their customers due to their high risks. Furthermore, due to the lack of labor force and high fixed costs shipyards generated large financial losses and became illiquid (Žužul, 2016). The weaknesses of Croatian shipbuilding industry are high produc- tion costs, lack of profitability and non-competitive product prices on the European and Asian markets. The long construction processes in comparison to other shipyards in Europe and worldwide, as well as failure in meeting delivery deadlines, are additional weaknesses and a financial burden for the industry (Bazina, 2016). Therefore, Croatian shipbuilding depends on direct (subsidies, grants, taking over the repayment of shipyards' debts to the national budget) and indirect state financial aid (provision of guarantees). At the beginning of the 1990s the government recognized the need to restructure the shipbuilding industry. More than HRK 30 billion (on average HRK 1.3 billion per year) were invested in the shipyards rehabilitation and restructuring in the period from 1992 until 2015 (Bazina, 2016). During the restructuring process, weaknesses such as technology gap, low productivity, high debt ratios, and low financial potential had to be solved. The main goals of the restructuring and privatization process of Croatian shipyards were rationalization and stabilization of their businesses as well as preparation for future independent operations on the global shipbuilding market while being compliant to all valid EU regulations (Bazina, 2016).

Based on the above-mentioned, the main models of managerial economics applied in the Croatian shipbuilding industry are as follow:

a. state financial aid (subsidies, guarantees, and takeovers of shipyards debts to the national budget)

b. industry restructuring, and

c. privatization.

Furthermore, the government supported the shipbuilding industry, not only through the Croatian Bank for Reconstruction and Development (hereafter HBOR), but also through export credit insurance programs. Hence, export credit insurance is an additional model of managerial economics that the Croatian government applies in the shipbuilding industry. Data on insured export turnover will be elaborated later on.

The first rescue cycle of the state-owned shipyards was done in the period from 1999 until 2001 and it was worth HRK 3.3 billion. The government wroteoff part of the largest shipyards' debt while the other part has been transferred into equity (Bajo et
Sopta, M., Šola, L.

Managerial aspect of shipbuilding through HBOR export credit insurance operations 
Sopta, M., Šola, L.

Managerial aspect of shipbuilding through HBOR export credit insurance operations

Table 1 Financial guarantees issued from 2007 to 2010 (in billions of HRK)

\begin{tabular}{|c|c|c|c|c|}
\hline & 2007 & 2008 & 2009 & 2010 \\
\hline Guarantees to shipbuilding sector & 4.5 & 2.55 & 2.04 & 4.57 \\
\hline Totally issued guarantees & 5.09 & 12.6 & 6.04 & 5.59 \\
\hline $\begin{array}{l}\text { Guarantees to shipbuilding sector as a percenta- } \\
\text { ge of totally issued guarantees }\end{array}$ & 88.5 & 20.3 & 33.8 & 81.7 \\
\hline
\end{tabular}

Source: Bajo et al (2016).

al., 2016).Additionally, the shipyards' debts to banks were transferred to the State Agency for Deposit Insurance and Bank Rehabilitation (DAB). The first rescue cycle resulted in technologically improved equipment for "Kraljevica d.d”. in 1999,"Uljanik d.d., "Brodograđevna industrija 3. Maj d.d., and "Brodosplit d.d." in 2000, and "Brodotrogir d.d." a year later (Perić Hadžić, 2013). The second rescue cycle started in 2002. The three largest Croatian shipyards were technologically upgraded in a modernization worth HRK 444 million. Moreover, the Croatian Shipbuilding Restructuring Commission was established in 2003, but there were no major changes in their business policies and business results. The latest rescue cycle of the Croatian shipyards started in the second half of 2006 when the Croatian Competition Agency (CCA), at the proposal of the Ministry of Economy, Entrepreneurship and Crafts, approved additional HRK 4.2 billion of state financial aid for the shipyards rescue (Perić Hadžić, 2013).

The largest share of government support to the Croatian shipbuilding industry is provided through state guarantees and rescue support for undertakings in difficulty. Rescue support for undertakings in difficulty includes direct payments to shipyards from the national budget and they are intended for salaries and procurement of necessary shipbuilding materials (Bazina, 2016). Most of the state financial guarantees for shipbuilding industry were issued in the period from 2007 to 2010 (Table 1). The shipyards have been privatized and restructured till 2012, and from that year the government no longer needed to issue so many loan guarantees. In the period between 1998 and 2015, the government paid HRK 12.5 billion for state guarantees and most of the funds (HRK 5.23 billion) were spent on the shipbuilding industry (Bajo et al., 2016).

Guarantees provided by HBOR are included in total state guarantees statistics as well. In the period from 1997 to 2010, HBOR has been providing guarantees worth on average HRK 1.3 billion per year.
The Republic of Croatia guarantees HBOR's liabilities jointly and separately, unconditionally, irrevocably, and on first call, without issuing any guarantee. HBOR state guarantees are mainly intended for the shipbuilding sector (Bajo and Primorac, 2011).

In accordance to the "Pre-accession economic program" (PEP) for 2004, the government announced privatization of the shipyards by the end of the year 2004. However, that year the privatization was not completed, not even partially. Thus, the government has continued covering losses of the shipyards. Following the government's decision on privatization of the shipyards, issued on May 21, 2008, three rounds of privatization tenders have been conducted. In order to attract the private sector and to privatize over indebted shipyards, in 2012 the government took over HRK 9.35 billion of the shipyards loan liabilities insured by state guarantees and transferred them to the national debt (Žužul, 2016). All major shipyards were restructured and privatized by the end of 2013. Shipyard "Viktor Lenac d.d." completed the restructuring and privatization process in 1993. Its two largest shareholders are "Tankerska plovidba d.d. Zadar" and "Uljanik d.d. Pula". The privatization of "Viktor Lenac d.d." and "Uljanik d.d." was done according to the employee ownership model. Thus, private individuals own the largest share of "Uljanik d.d." (46\%). "Uljanik d.d" owns $85.5 \%$ of "Brodograđevna industrija 3. maj d.d., "DIV shipbuilding d.0.0." owns $99.76 \%$ of "Brodosplit d.d.", and "Kermas Energija d.0.0." has 95\% ownership over "Brodotrogir d.d”. (Bajo et al., 2016). Croatian shipbuilding management models, state financial aid, industry restructuring and privatization, and export credit insurance cover important segments that have objective criteria. During the restructuring and privatization process, shipyards' long-term liabilities were decreasing while shortterm liabilities were gradually increasing. After the government transferred shipyard's long-term liabilities to the national debt, it has simultaneously 
significantly limited granting of guarantees. Hence, shipyards were not able to get high long-term loans. In 2014, shipyards' short-term liabilities accounted for $88 \%$ of their total liabilities.Although, shipyards' short-term liabilities have decreased right after the privatization process, soon they have continued to increase due to the increase in business activity. Most of the short-term liabilities are liabilities to suppliers and received advance payments liabilities that should be paid after the delivery of ships (Bajo et al., 2016).

Based on the shipbuilding industry financial analysis, Bajo at al. (2016) concluded that restructuring and privatization of shipyards had positive effects. Thus, it can be assumed that managerial models used in the Croatian shipbuilding industry have been logically consistent for many years. The theory of managerial economics is evaluated in different ways. Each theory is temporary and a subject for further development. Common and significant prediction mistakes are indisputable signs of a need for a new theory. The theory of the Croatian shipbuilding's managerial economics model primarily predicted operations rationalization and stabilization as well as addressing the technological gap, low productivity, high debt ratios, and over employment issues. Restructuring should have enabled independent and efficient operations on the international market according to market principles and existing EU rules and regulations. Privatization was a logical step towards strategic positioning of the shipbuilding industry, orientation towards related industries, expansion of market opportunities, and sales offer diversification. The question is: have the models of Croatian shipbuilding managerial economics met the theoretical predictions? In other words, has the state financial aid, provided during the shipbuilding restructuring and privatization process, resulted in the business stabilization and development?

Lack of competitiveness in the construction of standardized vessels has resulted in orientation toward the shipbuilding related industries and construction of specialized vessels. This decision had positive results and shipyards have successfully signed new contracts and ensured business continuation. Due to two cycles of technological modernization, the shipyards have obtained modern technological equipment, which is also one of the key factors for business continuation. Furthermore, in 2014 average industry net salary grew by $5.5 \%$ compared to 2013. Additionally, in the period from 2011 to 2014, the number of employees in large shipyards decreased by 25\% (Bazina, 2016). It solved the over-employment issue and allowed retraining and self-employment within the related industries. The restructuring process has resulted in a significant reduction of shipyards' long-term liabilities due to their transfer to national debt and the increase in short-term liabilities due to greater business activity. Furthermore, due to reduced total liabilities, the high debt-ratio issue was also solved. However, the negative side of the restructuring process is that the rescue of the Croatian shipbuilding industry has been financed by the government borrowings and had a great impact on the national debt of the Republic of Croatia (Bazina, 2016).

Brodotrogir in its financial statements emphasizes that the restructuring process has been successfully completed and that the company is profitable and operates efficaciously once again (Bazina, 2016). Thus, the answer to the previously stated questions is that the government has managed to stop the stagnation of Croatian shipbuilding industry by using managerial economics models such as subsidies, guarantees, industry restructuring, privatization, and export credit insurance.

\subsection{Position of the shipbuilding industry managerial economics in the scope of international economy}

Generally, the position of the shipbuilding industry managerial economics in the scope of international economy depends on the depth of enterprise's organizational structure. Thus, in multinational companies, that have a high hierarchical organization, strategically important decisions are made at the top level in their headquarters regardless of other markets importance. Connection and an established communication channel between the parent company and its subsidiary on the foreign market are extremely important. The speed of decision-making is the key for sales negotiations and inputs exchange while the production is dictated by sales specifics in the shipbuilding industry.

On the one hand, South Korean shipyards use inputs produced in their country for the construction
Sopta, M., Šola, L.

Managerial aspect of shipbuilding through HBOR export credit insurance operations 
Sopta, M., Šola, L.

Managerial aspect of shipbuilding through HBOR export credit insurance operations of standardized vessels. The production of such standardized vessels is not dictated by buyer's demands. The buyer buys an already made vessel at a set sales price. On the other hand, Croatia mostly produces specialized vessels where production is conditioned by customer's requirements. In order to find a contractor, the buyer announces an international tender with pre-defined requirements for the wanted vessel. Therefore, the price depends on the purchase price of raw materials that are often described in the tender. Since the price is not known in advance, it is important to find the cheapest possible but quality raw material. Hence, the shipbuilding suppliers' industry can hardly survive in Croatia as cheaper raw materials can be found in Southeast Asian countries in which the workforce is better educated and the labor costs per unit of production are much lower. Sales are made from national opportunities and in national interests, while the international economy for exports is more important than ever.

The shipbuilding industry in Southeast Asian countries receives high state aid because they believe that the development and expansion of this industry will boost their industrialization. Such measures made their progress faster than the one in the European shipyards in the segment of tankers and large containers (Kersan-Škabić, 2009). In the beginning of the 1970s, South Korea decided to direct a national strategy toward industry development and chose the shipbuilding industry as the national economy starter. At that time, South Korea began to conquer the market by offering lower shipbuilding prices than Japan and Europe. This led South Korea up to $25 \%$ of the world market share by the mid-1990s and made it the world's leading shipbuilding country in 2005. The Chinese market share has been growing rapidly over the last 10 years and has exceeded $30 \%$ in 2008, and by 2006 China became the second largest shipbuilding country in the world before Japan (Žužul, 2016). The production output in the shipbuilding industry is measured in delivered compensated gross tonnage (hereafter (GT) on an annual base. It is a sum of CGT of all ships delivered in the year of construction. The CGT is based on deadweight tonnage. DWT is the tonnage difference between a full and an empty ship. Asian countries are absolute leaders in shipbuilding according to the DWT criteria. China is the world's leading shipbuilding country and holds $42 \%$ of the World Order Book. It is followed by Japan (26\% of the World Order Book) and South Korea (about 24\%).

The European shipbuilding industry accounts for about $1.7 \%$ of the World Order Book. Out of all European countries, Spain holds the largest shareonly $0.38 \%$ (Hrvatska brodogradnja - Jadranbrod, 2017a). The European shipbuilding share in the world's shipbuilding is constantly declining. The European shipbuilding cannot be price-competitive to Asian countries because labor costs in Europe are considerably higher than in Asia and raw materials are more expensive in Europe than in the East. Results of the managerial economics of Croatian, European, and Asian shipyards can be analyzed through the following competitiveness indicators:

- productivity

- shipbuilding operations costs

- investments in research and development (R\&D).

Productivity is a ratio of output to input. The output is measured by the compensated gross tonnage method (cGT). Therefore, productivity in shipbuilding is measured in CGT per employee. The productivity of Croatian shipyards is 32 - 48 cGT per employee annually. Productivity in Japan is 115 CGT per employee and in Western Europe is about 80 cGT per employee. Thus, the productivity of Croatian shipyards is far below that of its competitors (Žužul, 2016).

Operation costs in shipbuilding consist of two parts: labor costs and all other indirect costs incurred by a shipyard. In Croatia, shipbuilding operation costs account for $35-40 \%$ of the total vessel costs, while in Europe it is $21 \%$ to $23 \%$, in Japan and South Korea 19\% and in India 8\% to 10\% (Žužul, 2016). Shipyards have a full control only on the productivity. In countries where labor costs are higher, most of the shipyards are trying to reduce the number of working hours needed to build vessels by investing in automation and R\&D. Such investments are becoming a key competitive factor in the shipbuilding industry. In Croatia, R\&D investments mainly depend on state grants and projects. On the global level, South Korea invests the most in its shipbuilding industry. At the EU level, Norway, Spain, Germa- 
ny, Italy and the Netherlands have the largest investments in shipbuilding (Žužul, 2016). European shipyards have developed a strategy of production of specialized ships with a high added value which requires the use of advanced technology and complex business processes to build. Croatian shipyards are striving to implement such strategy too. Due to these factors, Europe is still dominating in several specialized market segments such as cruise vessels (99\% of the world market share), bay vessels (43\% of the world market) and luxury yachts (65\% of the world market) (Sokolić, 2008).

The key of East Asian countries' success is in their managerial economics. South Korea has been one of the world leaders in the shipbuilding industry for many years. Their Order Book grew from 9.6 billion CGT in 1998 to 64.4 billion CGT in 2008 (Žužul, 2016). In order to get rid of unprofitable shipyards, the Korean government would withdraw its help in case some particular shipyard was unsuccessful, and businesses would be left to go bankrupt. As there were no domestic suppliers for the shipbuilding industry, the government shifted its focus to the development of the shipbuilding suppliers' industry, which increased outsourcing but reduced imports from $70 \%$ in 1975 to only $20 \%$ in 2016. Thus, about $90 \%$ of marine equipment and materials used in standardized vessels production in South Korea are manufactured in South Korea (Žužul, 2016).

Japanese shipyards are focused on the development of the vessel of the future - the unmanned cargo vessel. "Smart vessels" will use artificial intelligence to achieve safer and shorter sailing. Such ships are announced to get into exploitation by 2025. Furthermore, Japanese shipyards buy Chinese, Philippine, and Vietnamese shipyards in order to get cheaper labor force and achieve a more competitive market position (Hrvatska brodogradnja Jadranbrod, 2017a).

Croatian shipyards are still in the restructuring process. From the end of July 2017 until mid-2019, Croatian shipyards have contracted deliveries of 42 vessels of a total value of about USD 1.68 billion, out of which $98.2 \%$ are intended for export $(\mathrm{Hr}$ vatska brodogradnja Jadranbrod, 2017a). Since the restructuring process is ending shortly ("3. Maj" on December 31, 2017, "Brodosplit" on February 28, 2018, and "Brodotrogir" on April 6, 2018) all Cro- atian shipyards are facing great challenges on how to continue to ensure contracting a sufficient quantity of quality jobs and how to ensure sustainable operations on a demanding market without state aid.

\section{HBOR's capabilities and limi- tations in providing support for shipbuilding industry through export credit insurance operations}

\subsection{Shipbuilding industry export credit insurance}

Taking into consideration a high level of risk that is present in the shipbuilding industry, the impact of HBOR's export credit insurance operations is huge. As mentioned before, some of the main characteristics of the shipbuilding industry projects are capital intensity, long business cycles and low profitability. Furthermore, negotiation of new contracts takes a lot of time and buyers usually pay in advance or during the production only a smaller part of the contract while the rest is paid after the delivery. Moreover, there is a high risk that raw material prices may increase after the contract signing. Thus, steel is the most often used material and its price is extremely important since it affects financing and projection of costs of the project. Additionally, there is a currency risk as well (Bazina, 2016). Therefore, for the private market, i.e. commercial banks, which are capable to take over only a small part of export risks, this sector is highly risky. Through its export credit insurance operations, HBOR reduces commercial and political risks to insurers (exporters and banks). Moreover, HBOR's insurance of export credits, claim collections, and guarantees has a positive impact on the development of the shipbuilding suppliers' industry and export growth. Therefore, it reduces the industry's import dependence and increases the shipbuilding industry's multiplier effect. Finally, a binding or non-binding letter of intent for insurance is often used as an elimination criterion for the international tender application for construction of new vessels or for the repair of existing ones. HBOR provides Croatian exporters with such letters of intent and makes it possible for them to apply to international tenders and increases their likelihood of winning them. In conclusion, HBOR's
Sopta, M., Šola, L.

Managerial aspect of shipbuilding through HBOR export credit insurance operations 
Sopta, M., Šola, L.

Managerial aspect of shipbuilding through HBOR export credit insurance operations export credit insurance services in the shipbuilding industry have two fundamental goals:

a. to create preconditions for the increase of Croatian shipyard's international competitiveness by:

(i) risk reduction and risk-sharing at foreign market entrance stage

(ii) enabling sales with postponed payments

(iii) enabling banks to provide loans to buyers

(iv) financing exporters at the pre-export stage, and

(v) providing guarantees for applications to international tenders.

b. to create preconditions for the increase of the shipbuilding industry's multiplier effect on the national economy by:

(i) supporting the development of the shipbuilding suppliers' industry

(ii) supporting the employment growth in the shipbuilding industry and related industries, and

(iii) supporting a more favorable balance of Croatia's Book of Payments.

\subsection{Capabilities and limitations}

As a response to economic crisis in the Republic of Croatia, the HBOR has developed a support system for exporters, especially the ones from the shipbuilding industry. Thus, the HBOR, through its export credit insurance programs continued to support exporters even when commercial banks would not provide financial support due to their poor financial position and lack of acceptable collaterals. However, after the global economic crisis hit the world market in 2008, the HBOR has been facing more and more constraints in supporting the shipbuilding industry through export credit insurance services. There was a large increase in share of domestic risk in the export credit insurance port- folio in the period from 1999 till the end of 2016 due to a huge interest of banks and exporters for insurance policies that cover exporters' risk. Thus, in 2012 domestic risks accounted for $15 \%$ of the total risk of the portfolio (HBOR, 2014), while on December 31,2016 , the share was $37 \%$ (HBOR, 2017a). After several exporters found themselves in a poor financial position and started the pre-bankruptcy settlement processes, the former insurance portfolio that covered domestic risks became highly risky. Consequently, that had a great impact on reservations of funds for potential indemnity payments as well as on the eventual Guarantee Fund's balance.

On December 31, 2016, the HBOR's export credits risk exposure for shipbuilding industry exports was EUR 71.327 .582 (about HRK 528.34 million). It represented $31.79 \%$ of the HBOR's total gross exposure for all insurance policies, or $86.33 \%$ of total insured domestic risks (HBOR, 2017a). Gross exposure is the sum of all active insurances. Thus, it includes the insured party's risk share (exporter or commercial bank). In other words, it represents the total amount insured by the HBOR. The data provided above shows that a great part of the total export credit insurance portfolio's risk is concentrated in the shipbuilding industry.

Net exposure for all export credit insurance activities on December 31, 2016 was HRK 1.35 billion (HBOR, 2017b), while the Guarantee Fund's balance was HRK 332.4 million (HBOR, 2017c). Net exposure is the sum of all active insurances less the self-retention. Thus, it does not include the insured party's risk share. Therefore, net exposure represents the amount of all potential indemnity payments in case all insurance portfolio risks are realized in their maximum amounts. The HBOR's Guarantee Fund accounted for $24.63 \%$ of its net exposure while domestic risk represented $37 \%$ of the total portfolio's risk.

Table 2 shows the trend of the Guarantee Fund coverage of the HBOR's net exposure for four years.

Table 2 Guarantee Fund coverage of the total net exposure from 2013 to 2016

\begin{tabular}{|l|c|c|c|c|}
\hline & 31.12 .2013 & 31.12 .2014 & 31.12 .2015 & 31.12 .2016 \\
\hline Guarantee Fund balance (HRK) & 174.356 .415 & 276.657 .023 & 310.798 .741 & 332.359 .174 \\
\hline Total net exposure (HRK) & 1.340 .111 .905 & 1.344 .245 .188 & 1.547 .902 .712 & 1.350 .384 .922 \\
\hline Guarantee Fund to net exposure ratio & $13 \%$ & $21 \%$ & $20 \%$ & $25 \%$ \\
\hline
\end{tabular}

Source: HBOR's internal records and reports. 
On December 31, 2013, the Guarantee Fund to net exposure ratio was the lowest, $13 \%$. In case the domestic risk exposure suddenly increases, the Guarantee Fund to net exposure ratio would fall below 8\%.As an example, if several insured shipyards from the export credit insurance portfolio declare bankruptcy or liquidation, payment of indemnities from the Guarantee Fund or directly from the national budget would affect the liquidity of the Republic of Croatia. Furthermore, the HBOR's capacities to provide new export credit insurance services and to continue to be a national insurer would definitely be exhausted. In conclusion, the HBOR's reputation as a national export credit agency and its entire business operations would be jeopardized by the export credit insurance services. Due to the worsening of the export credit insurance portfolio's structure and quality, further indemnity payments would become impossible as well as further insurance of acceptable risks.

In order to improve the management of the export credit insurance portfolio, as well as to increase the quality of the portfolio and to reduce its future risk, in agreement with the Supervisory Board of HBOR and the Export Insurance Committee, in January 2013, the HBOR has introduced additional measures for the management of the export credit insurance portfolio (HBOR, 2014):

a. the Guarantee Fund to net exposure ratio should not be lower than $8 \%$

b. in case of a significant increase in risk-weighted exposure, the insurance conditions should be made stricter

c. transactions with the individual risk exceeding the Guarantee Fund's balance at the time of the insurance approval should not be insured

d. actual loss ratio should not exceed $75 \%$ of the estimated loss ratio, and

e. the domestic risk net exposure should not exceed $25 \%$ of the total net exposure.

In order to reduce the domestic risks exposure, the HBOR, as a national insurer, may insure foreign buyers' commercial and political risks through its export credit insurance programs. Thus, the HBOR is able to take over the risk of non-payment by a foreign buyer for Croatian vessels as well as polit- ical risks which may result in non-payment (especially in countries with high political risk). Moreover, the insurance of foreign buyers' risks increases the competitiveness of Croatian shipyards in foreign markets and supports the internationalization of Croatian exports and the shipbuilding industry.

\subsection{Impact of the OECD and the European Commission directives on the HBOR's export credit insurance business}

The Organization for Economic Cooperation and Development (hereafter OECD) is an international economic organization founded in 1961. The OEEC was established in 1948 with the initial goal to help rebuild Europe destroyed in the World War II. The OECD has been developing over the years and its current goals are to support the development of the world economy and expand and enhance international trade in member states. The organization has a long tradition of creating rules in the field of export loans with public support. The OECD currently consists of 34 member states (OECD, 2017a). Furthermore, the Exports Credit Insurance working group (hereafter ECG) was founded in 1963. It has the task to improve OECD's operations in the field of export credits.All OECD member states are members of the ECG too, except Chile and Iceland. The European Commission also participates in the ECG meetings. Moreover, the Berne Union, the IMF, the EBRD, the UNEP and the World Bank actively participate in ECG meetings as well (European Council, 2017).

The OECD Agreement is a document that defines the fundamental common set of export credit insurance policies among the signatories. The Agreement defines the terms under which states may finance and/or insure export contracts. It determines a range of elements such as minimum down payments, maximum official support and local cost, maximum repayment terms, principal repayment and interest payment dynamics, premium rate, interest rates, principles of risk assessment and many other elements and conditions related to export credits (OECD, 2017b).

The OECD Agreement has the following goals:

a. protection against market competition violation on foreign markets caused by various "state financial aid" through direct loans or
Sopta, M., Šola, L.

Managerial aspect of shipbuilding through HBOR export credit insurance operations 
Sopta, M., Šola, L.

Managerial aspect of shipbuilding through HBOR export credit insurance operations

\section{insurance policies}

b. support for export credit transactions that are in line with the principles of corporate social responsibility, environment protection, human rights, sustainable lending to poor countries, and the fight against corruption.

The OECD Agreement applies to export credits with repayment terms of two years or longer, except for agriculture and military equipment credits. Some industries have special technical and financial characteristics. Financial rules for such industries are defined in separate agreements called Sector Understandings. There are four Sector Understandings which are an integral part of the OECD Agreement. They define rules for shipbuilding, nuclear power plants, civil aviation, and renewable energy and water management industries. Sector Understandings reflect the fact that these industries require specific rules which are adapted to industries' market needs, building and financing requirements, financial conditions and member states' politics (OECD, 2017c). The OECD Agreement defines minimum premium rates (hereafter MPR) that the member states' export credit agencies should charge for credit risk coverage. They should be in accordance with the real risks and be sufficient for long-term operating costs coverage as well as for possible indemnity payments. Equal MPRs are determined with a goal to establish a comparable system that allows the exchange of goods and services according to equal rules and competition on quality of goods and services instead of terms of state credits or insurance policies. MPRs are calculated for countries in seven categories. For countries that fall into the category zero (highly developed OECD member countries and most of the EU countries) MPR is not defined (OECD, 2017d).

The OECD Agreement is incorporated into the EU legal framework by the EU Regulation No. $1233 / 2011$ of the European Parliament and of the Council. It is enforceable in all EU member States (The Publications Office of the European Union, 2016). Although the Republic of Croatia is not a member of the OECD, the HBOR, as an export bank and export credit agency of the Republic of Croatia, has decided to achieve corporate social responsibility goals and applied relevant OECD recommen- dations, principles, and guidelines. After joining the EU, Croatia is obliged to comply with the OECD Agreement. However, even before Croatia joined the EU the HBOR in its operations was already following all OECD Agreement directives, except the ones regarding MPRs. Therefore, necessary changes have been applied to the premium system in order to make the HBOR fully compliant with the OECD Agreement. The HBOR's Export Credit Insurance division is now obliged to apply MPRs for premiums calculations for export credit insurances with repayment terms of two years or longer (except for agriculture and military equipment credits). Such adjustments reduced the HBOR's reputational risk since it became compliant with all relevant regulations and practices of the most developed export credit agencies. MPRs defined by the OECD Agreement were higher than the premium rates in the HBOR's previous premium system. Thus, the changes resulted in an increase in profits due to an increase in income from premiums for insurance of credits with repayment terms of two years or longer (HBOR, 2013).

At the same time in 2013, the HBOR has started to apply the OECD Guidelines on corporate social responsibility and developed and adopted its own Policy on the application of the OECD Guidelines on corporate social responsibility. Specific actions were defined in three policies (HBOR, 2013):

- policy on the application of the OECD Recommendation of the Council on common approaches for officially supported export credits and environmental and social due diligence

- policy on the application of the OECD Principles and Guidelines to promote sustainable lending practices in the provision of official export credits to low income countries

- policy on the application of the OECD Council Recommendation on Bribery and Officially Supported Export Credits.

The HBOR, as a national export credit agency, also faces compliance restrictions on state financial aid in the form of guarantees (based on the Commission Notice on the application of Articles 87 and 88 of the EC Treaty to State aid in the form of guarantees (2008/C 155/02) and the State Aid Act (NN 
47/14). In insurance programs that cover exporter's risks (pre-export financing insurance and insurance of performance-related export guarantees) the following conditions should be met so that support is not considered to be a state financial aid (Narodne novine, 2009):

a. The borrower is not in financial difficulties. If a borrower is in financial difficulties, the private investor test would be satisfied only in the case that the HBOR in a similar situation (the "pari passu" model) would make the same transaction at exactly the same conditions as would a commercial bank. In that situation, the risk would be split 50:50 between the HBOR and the commercial bank. Therefore, since the HBOR as a national export credit agency needs to comply with the state aid rules, it is not able to insure loans and/or guarantees for export transactions which involve risk of exporters in financial difficulties. The exception is the case of a "pari passu" model when the risk is shared with a private market entity at an equal ratio, so that the market investor test is satisfied (HBOR, 2014).

b. The guarantee's scope can be properly measured. The guarantee must be linked to a particular financial transaction, have a fixed maximum amount, and be time-limited. Thus, the Commission considers unlimited guarantees to be incompliant with the Article 87 of the EC Treaty.

c. State guarantee does not cover more than $80 \%$ of unpaid loan or other financial obligation. If a Member State wishes to provide a guarantee over an $80 \%$ limit and claims that it is not a state aid, it should prove the claim on the basis of the entire transaction's arrangement and report it to the Commission in order to allow its properly assess whether the guarantee is a state aid or not.

d. Market risk premium is paid for the guarantee. The guarantee is not classified as state aid when the premium paid for the guarantee is at least as high as the corresponding reference value for the guarantee premiums found on the financial markets. Otherwise, if an appropriate reference value for guarantee premiums cannot be found on financial markets, the total financial cost of the guaranteed loan (loan interest rate and guarantee premium) must be compared to a market price of a similar loan without guarantee. In both cases, in order to determine an appropriate market price, the following characteristics of the guarantee and the underlying loan should be taken into account:

(i) amount and repayment terms of the transaction

(ii) insurance provided by the borrower and other experiences that may affect estimates of repayment rate

(iii) probability of non-fulfillment of the borrower's obligations which arises from its financial situation, sector of activity and expectations.

\section{Export credit insurance business analysis}

\subsection{The HBOR's shipbuilding export credit insurance services for and on behalf of the Republic of Croatia}

Since 1998 till the end of 2016, HBOR as an insurer has insured a total of HRK 22.6 billion of export transactions. Most of the insured turnover (61\%) refers to short-term insurance. During the same period, the HBOR earned HRK 163 million as insurance premiums and paid out HRK 125.6 million as indemnities and expenses. Since indemnities and expenses paid are less than received insurance premiums and recourses, the HBOR achieved a loss ratio of $73 \%$ (HBOR, 2017g) or, in other words, the HBOR has achieved a positive cash result. The loss ratio is a ratio of total paid indemnities and expenses to the total received premiums and recourses. During the same period, HRK 1.49 billion of the shipbuilding industry export operations were insured. This is $6.62 \%$ of the mentioned above total value of insured export transactions. The largest shares of the total insured shipbuilding exports are to the markets of Luxembourg (HRK 438.3 million or 29.33\%), Monaco (HRK 341.2 million or 22.83\%), and Russia (HRK 277.4 million or 18.56\%) (HBOR's internal database).
Sopta, M., Šola, L.

Managerial aspect of shipbuilding through HBOR export credit insurance operations 
Sopta, M., Šola, L.

Managerial aspect of shipbuilding through HBOR export credit insurance operations
In the shipbuilding sector the following export credit insurance programs are used:

a. program for pre-export financing insurance

b. program for insurance of performance-related export guarantees

c. program for insurance of buyer credit or buyer's bank credit, and

d. program for insurance of direct deliveries of goods and services (supplier credit).

\subsubsection{Program for pre-export financing insurance}

The pre-export loan covers the lack of liquid assets, or in other words, it is used to finance preparation activities (procurement of raw materials, procurement of equipment for production, production of goods, labor force, etc.) and payments collection. For the approval of such loans used for preparation activities and payments collection, commercial banks require insurance instruments that exporters often do not have. The HBOR's loan insurance policy can be accepted by banks as an intangible loan protection and can be used as a credit risk reduction technique. Such loan is granted to the exporter, which means it represents a domestic risk for the HBOR. An insurance contract is signed by the HBOR, the exporter, and the exporter's bank that approves the loan. The exporter uses the loan for production of goods and services which it then delivers to a foreign buyer. In case the exporter does not repay the loan, the HBOR pays indemnities to the exporter's bank (HBOR, 2017g). In the period from 1999 until the end of 2016, HRK 796.9 million (HBOR, 2017g) of loan coverage was approved through the pre-export financing insurance program. The shipbuilding industry had a share of $39.9 \%$. Such a significant share of the shipbuilding industry is explained by the fact that loans value for Croatian shipbuilding export projects are much higher than loans value in other industries. The largest insured value of HRK 15.2 million had a loan for the preparation of construction of the passenger sailing boat which will be exported to Monaco. All pre-export financing insurance policies for the shipbuilding industry were approved in the year 2016.All of them are still valid and will last no later than the first half of the year 2019. Their total value is HRK 318 million (HBOR's internal database).

\subsubsection{Program for insurance of performance- related export guarantees}

The performance-related bank guarantee is an instrument which banks use to guarantee in favor of a user for a particular job. It can be issued by private or state banks. Such insurance policies are intended for exporters which need to issue guarantees in favor of their foreign buyers as a condition for the conclusion or best execution of export contracts. Therefore, as it is the case with loan insurances, the issue of performance-related bank guarantee is also a domestic risk for the HBOR. There are several types of performance-related guarantees: bid bond or tender guarantees, advance payment guarantees, or repayment guarantees, performance guarantees, and other guarantees (Vukojević, 2015). The HBOR's guarantee policy serves as collateral for the issuance of guarantees by other banks and replaces insurance instruments which other banks usually ask as collaterals (for instance real estate, property, etc.). The policy covers the risk of an unfair call for payment by the beneficiary of the guarantee despite a proper fulfillment of the exporter's obligations and political risk that might prevent a proper fulfilment of exporter's obligations. In such cases, the HBOR will pay indemnities to the exporter's bank and will not be reimbursed by the exporter. In case of a fair call for payment, the HBOR will pay indemnities to the exporter's bank but will be later reimbursed by the exporter (HBOR, 2017f). The insurance contract is signed by the HBOR, the exporter and the exporter's bank. The exporter's bank, at the call of the exporter, issues a guarantee in favor of a foreign buyer. In case that the insured risks occur, the foreign buyer will be reimbursed according to the guarantee and the HBOR will pay indemnities to the bank. Which party the HBOR will call for recourse payments depends on whether it was a fair or unfair call. In case of a fair call, the HBOR calls the exporter. Otherwise, the HBOR calls the foreign buyer or a third party (HBOR, 2017e). In the period from 1999 until the end of 2016 the total value of issued insurance policies through the program of insurance of performance-related export guarantees was HRK 1.53 billion (HBOR, 2017g). The shipbuilding industry had a $41.6 \%$ share with a total value of issued policies for insurance of performance-related export guarantees of 
HRK 636.8 million. The largest insured value of HRK 386.3 million had a counter-guarantee for the export project for the construction of a multipurpose vessel for special works at sea which has been delivered to a foreign buyer in Luxembourg (HBOR's internal database).

\subsubsection{Program for insurance of buyer credit or buyer's bank credit and insurance of direct deliveries of goods and services}

The loan for a foreign buyer may be granted directly to the buyer or to the exporter's bank. Payments for the loan are paid to the exporter by the HBOR, and then they are demanded from the debtor (foreign buyer or its bank). Such loans provide buyers with an opportunity to purchase capital goods and equipment of higher value with the delay of payment, while the exporter receives funds immediately upon the delivery of goods to its foreign buyer. The realization of such placement is possible due to the loan insurance policy issued to the buyer by the $H B O R$ under the insurance contract. By such insurance contract the HBOR takes over the loan repayment risk up to $95 \%$ of principal and regular interest. If the foreign buyer or the bank does not repay the loan, the HBOR pays indemnities to the exporter's bank (HBOR's internal database). In the period from 1999 until the end of 2016 the total value of issued insurance policies, through the program of insurance of buyer credit or buyer's bank credit, was HRK 1.2 billion (HBOR's internal database). The shipbuilding industry had a $38.1 \%$ share with a total value of issued policies for insurance of buyer credit or buyer's bank credit of HRK 467.5 million. The largest insured value of HRK 190.1 million had a loan for an export project for the construction of a passenger sailing boat which will be exported to Monaco.

Loans for direct deliveries of goods and services (supplier loan, commodity loan) are approved by the exporter's bank, while an insurance policy is issued by the HBOR and serves as an insurance instrument. The exporter and the HBOR sign an insurance contract and the exporter pays an insurance premium. In case the buyer does not pay for delivered goods, the HBOR will pay the indemnity to the exporter or the bank if the exporter has transferred its insurance policy in favor of the bank.
The transfer of the insurance policy in favor of the bank is a transfer of rights to the bank (creditor) for payments of the insured amount but only up to the amount of the debtor's debt on the loan to which the vinculated policy is linked as a loan repayment instrument to finance the export business (HBOR, 2017e). In the period from 1999 until the end of 2016 the total value of issued insurance policies through the insurance of direct deliveries of goods and services program was HRK 1.2 billion (HBOR, 2017d). The shipbuilding industry had a $4.1 \%$ share with a total value of issued policies for insurance of direct deliveries of goods and services of HRK 72.3 million (HBOR's internal database). The largest insured value of HRK 45.2 million had a commodity loan for the construction of a vessel which has been exported to Turkmenistan.

\subsection{Challenges of the export credit insurance business in the shipbuilding industry}

The goal of the above-mentioned export credit insurance programs is to encourage Croatian export and the internationalization of operations by increasing the competitiveness of Croatian exporters on the foreign markets. Among other things, this is achieved by reducing and sharing of risks which Croatian exporters encounter when they enter foreign markets. Through the HBOR as an export credit agency, the state directly takes over risks which are not "interesting" to the private market due to long repayment terms, too large or too small transaction amounts, or too high political risk of the target country. According to our professional opinion and experience in practice, we list the following challenges which export credit insurance business faces in the shipbuilding industry:

a. Transactions size and long repayment terms. The value of insured claims within the shipbuilding industry is often very high, which is normal because it is a capital-intensive industry. Additional measures for the management of export credit insurance portfolio have been adopted in January 2013. They enable better monitoring of transactions where an individual risk exceeds the Guarantee Fund balance at the time of insurance approval. The Guarantee Fund balance on December 31, 2016, was HRK 332.4 million
Sopta, M., Šola, L.

Managerial aspect of shipbuilding through HBOR export credit insurance operations 
Sopta, M., Šola, L.

Managerial aspect of shipbuilding through HBOR export credit insurance operations which means that the insured amount of a single export transaction should not exceed the amount of HRK 332.4 million. The loan repayment terms and guarantee terms relate to a longer period of time, and the HBOR's exposure to their risk as the Insurer is for the equivalent period of time.

b. Too large exposure to domestic risks. Due to the large interest of commercial banks and exporters for guarantee insurance policies and pre-export financing insurance policies that cover a domestic risk, the share of domestic risk in the export credit insurance portfolio increased to $37 \%$. The shipbuiIding industry has the largest share in the portfolio of insured domestic risks, $86.33 \%$ of total risk. After several exporters found themselves in poor financial position the insurance portfolio that covered domestic risks became highly risky. One of the additional measures for the export credit insurance portfolio management is to monitor the domestic risk net exposure share in the total net exposure. Due to continued great interest in the insurance programs that insure domestic risks, compliance to the set measure is certainly one of the business challenges.

c. Unwillingness of commercial banks for the approval of loans and guarantees. There are many reasons why commercial banks may show an unwillingness to engage in export business as creditors. One of the problems is the lack of insurance instruments on the exporter's side. Furthermore, some banks may have a predetermined maximum repayment terms over which they do not engage in credit negotiations. Other reasons are: unfamiliarity with the industry, lack of experience on particular markets (for instance export to countries that apply sharia law requires knowledge of the sharia (aw), a high export risk to countries under sanctions, etc. The HBOR's insurance policy is accepted as a solution to the mentioned issues because it is recognized as an intangible loan insurance for banks and can be accepted as a credit risk reduction technique. Still, due to the level of risk for commercial banks, this may be insufficient.

d. International restrictions (sanctions) and political risks.Assuming that the export contract is agreed upon and signed as well as the insurance policy, the introduction of sanctions toward foreign buyer's country by the EU or vice versa does not affect the export business. If sanctions or the realization of other political risks (war, riot, or revolution) directly affect the export business, it may result in prolongation of delivery deadlines, problems in the transfer of a transaction, non-payment, bankruptcy or liquidation of the contractor, cancellation of the export contract and so on. As a consequence, the HBOR's export credit insurance portfolio will be affected as well. Unfortunately, the export credit insurance department cannot have an impact on the decision regarding imposition of sanctions on the foreign buyer's country, but it can keep the conservative attitude in the assessment of export target countries' risks, the creditworthiness of external debtors and the export credit insurance business.

\subsection{Impact of the HBOR's export credit insurance business on the shipbuilding industry}

Export credit insurance activities represent an additional model of the managerial economics by means of which the state influences the shipbuilding industry with a purpose to reduce risk exposure and to increase the competitiveness of Croatian shipyards abroad. So far, exports insurance has insured a total of HRK 1.49 billion of export turnover of Croatian shipbuilding industry. The biggest demand is for the insurance of performance-related export guarantees and it has provided the largest number of export projects. Nine Croatian shipyards' export projects with HRK 636.8 million of the total value of their insurance policies were insured through the insurance of performance-related export guarantees (HBOR's internal database).

The least amount of export turnover was insured through the insurance of direct deliveries of goods and services. 
Table 3 Total insured export turnover and number of export projects of Croatian shipbuilding by HBOR's export credit insurance programs (from 1999 until the end of 2016)

\begin{tabular}{|c|c|c|}
\hline Program & Insured amount (HRK) & Number of export projects \\
\hline $\begin{array}{l}\text { Insurance of performance-related export } \\
\text { guarantees }\end{array}$ & 636.786 .651 & 9 projects \\
\hline $\begin{array}{l}\text { Insurance of buyer credit or buyer's } \\
\text { bank credit }\end{array}$ & 467.445 .685 & 4 projects \\
\hline Pre-export financing insurance & 317.982 .644 & 3 projects \\
\hline $\begin{array}{l}\text { Insurance of direct deliveries of goods } \\
\text { and services (supplier credit) }\end{array}$ & 72.288 .855 & 2 projects \\
\hline Total & 1.494 .503 .834 & 18 projects \\
\hline
\end{tabular}

Source: HBOR's internal records and reports.

Taking into account the so far insured export turnover of Croatian shipbuilding and the number of export projects, the export credit insurance activities affect the shipbuilding industry in direct and indirect ways. Due to their connection with export, the direct effects of export credit insurance on shipbuilding are visible in:

(i) the improvement of the position and competitiveness of the industry on the world market

(ii) the spread to new markets, and

(iii) the more favorable balance of the state's balance of international payments.

Despite the stagnation of the world shipbuilding market and the long restructuring process, the share of new construction orders from Croatian shipyards on the European and World markets is increasing. According to the European Book of Orders, Croatia had $11.66 \%$ of the European market two years ago, while today it has $20.56 \%$ of the market which is the second in Europe. Croatia had 0.19\% of the world market two years ago, while today it has $0.35 \%$ which is the ninth in the world (Hrvatska brodogradnja - Jadranbrod, 2017a). According to HBOR's internal records, Croatian shipyards export to Luxembourg, Monaco, Russia, Turkmenistan, Greece and the Netherlands (HBOR's internal reports). According to Croatia's Book of Current Orders, shipyards will soon export to the markets of the Cayman Islands, Kuwait, Singapore, Canada, Malta, Cyprus, Sweden, Marshall Islands, Norway and Finland (Hrvatska brodogradnja - Jadranbrod, 2017b). The Balance of International Payments of the shipbuilding sector is variable as everything depends on contracted export jobs that will be implemented in several years upon delivery of the ship. Over the last three years, the export of Croatian shipbuilding industry grew the most in the year of 2015, when compared to the previous year, it grew by $118.2 \%$. From the year 2014 to the year 2016, exports have increased by $15.5 \%$, from HRK 1.3 million to HRK 1.5 million. The Balance of International Payments of the shipbuilding industry in the year of 2016 had a surplus of HRK 843 million. In the first quarter of the year 2017, the exports of Croatian shipbuilding industry were HRK 681.8 million, which means an increase of about $80.8 \%$ from the year 2016 on annual basis. If the growth trend continues until the end of the year 2017, exports could reach the levels from 2015.

The indirect effects are hardly measurable, but the export credit insurance business has a positive influence on:

(i) the recovery and development of Croatian shipyards

(ii) development of the supporting industries; and

(iii) increasing of the multiplicative effect of
Sopta, M., Šola, L.

Managerial aspect of shipbuilding through HBOR export credit insurance operations

Table 4 Balance of International Payments of the shipbuilding industry from the beginning of the year 2014 till the end of the first quarter of 2017

\begin{tabular}{|l|c|c|c|c|}
\hline & 2014 & 2015 & 2016 & 102017 \\
\hline Export of shipbuilding industry (HRK) & 1.306 .609 .976 & 2.805 .827 .175 & 1.508 .819 .130 & 681.836 .125 \\
\hline Import of shipbuilding industry (HRK) & 1.041 .098 .699 & 811.972 .365 & 665.808 .970 & 229.482 .186 \\
\hline Balance of Payments (HRK) & 265.511 .277 & 2.038 .854 .810 & 843.010 .160 & 452.353 .939 \\
\hline
\end{tabular}

Source: DZS (2017). 
Sopta, M., Šola, L.

Managerial aspect of shipbuilding through HBOR export credit insurance operations the shipbuilding industry on the national economy.

According to Bajo et al. (2016), the Croatian shipyards have satisfactory liquidity. All liquidity indicators in the year of 2012 grew due to the state taking over of their obligations. Assets turnover ratios indicate that shipyards lack a larger market share. In general, after the restructuring of shipyards, debt ratio stayed within acceptable limits. The efficiency of operations and sales in the year of 2014 is lower than 1 , which means that expenses exceed revenues. From the year 2011 until the year of 2014, the number of employees in large shipyards decreased by around 2,700 or by $25.5 \%$, while the average monthly net salary in the year of 2014 has increased by $5.5 \%$ compared to the year of 2013 . The share of workers in the shipbuilding industry is gradually decreasing as a result of restructuring and efforts to make shipyards financially healthy and independent of state aid entities (Bajo et al., 2016). Export credit insurance activities cannot be characterized as state's aid because they are not, and should not be according to EU regulations. In conclusion, HBOR's export credit insurance activities enable Croatian exporters to apply for international tenders and increase their likelihood of winning them. It also has a positive impact on the development of the supporting industries and increases exports, which consequently increases the positive multiplication effect of the shipbuilding industry. Furthermore, the issuance of insurance policies reduces the commercial and political risks of insured entities. Finally, export credit insurance activities increase the competitiveness of Croatian shipyards abroad and this is their core function.

\section{Conclusion}

The shipbuilding sector is a strategically important industry for the Republic of Croatia due to its multiplier effect on the national economy and region in which the activity takes place. It has a total turnover of almost HRK 2 billion and employs around 11.000 workers. The managerial economics models which are used in the Croatian shipbuilding industry are the following: state's financial support, restructuring, privatization and export credit insurance activities. Their main goals are business rationalization and stabilization, preparation for independent sus- tainable operations, increase in competitiveness on the international market and risk reduction. From 1992 until 2015 the state has invested more than HRK 30 billion in the rehabilitation and restructuring of the shipbuilding industry. The government has effectively stopped the stagnation of the Croatian shipbuilding, but the negative side is the fact that the public debt mostly finances the survival of the Croatian shipbuilding industry. The world's leading shipbuilding country is China with about $42 \%$ share in the World Book of Orders, followed by Japan with about $26 \%$ share, and South Korea with about 24\%. The background of the South Korean shipbuilding industry growth is that the government has set shipbuilding as a strategic industry for economic growth. The Korean government has the practice according to which, in case a particular shipyard is unsuccessful, the government's aid would be withdrawn, and business would be left to go bankrupt. The state shifted its focus to the development of a supplier network, which increased outsourcing but reduced the import. The demand for ships on the world market has stagnated since 2015. The growth of demand for ships on the world market depends on the economic development as well as the development of maritime freight traffic. Taking into consideration a high level of risk, the impact of HBOR's export credit insurance activities on the shipbuilding industry is high. Due to long maturity, capital intensity and lack of collaterals, crediting the shipbuilding industry is not attractive for commercial banks. On December 31, 2016, HBOR's exposure to the shipbuilding sector was $31.79 \%$ of the total insurance portfolio. From 1998 until 2016, HBOR insured a total value of HRK 1.49 billion of Croatian shipbuilding industry export. The largest share of total shipbuilding industry export was to the markets of Luxembourg (HRK 438.3 million or 29.33\%), Monaco (HRK 341.2 million or 22.83\%), and Russia (HRK 277.4 million or $18.56 \%$ ). Business challenges for export credit insurance are: transaction size, long maturity, large exposure of portfolio to domestic risks, lack of willingness of commercial banks to provide loans and guarantees, and sanctions and political risks. Export credit insurance services directly allow Croatian exporters to apply for international tenders and increase their likelihood of winning them. It also has a positive impact on the development of the 
supporting industries and increases exports, what in result increases the positive multiplication effect of the shipbuilding industry. Export credit insurance services increase the competitiveness of Croatian shipyards abroad and this is their core function. The topic is generally poorly researched by the science community in Croatia, therefore sources of literature are limited. Primary research of the
Croatian largest shipyards is required for ongoing research. Furthermore, research should be expanded by observations of other market's segments. By adding primary research methods, which include interviews and questionnaires, the impact of the HBOR's export credit insurance business on the shipbuilding industry would be understood from the shipyards' perspective.

\section{Literature}

Bajo, A., Primorac, M. (2011) Državna jamstva i javni dug Republike Hrvatske. Zagreb: Institute of Public Finance [online]. Available at: https://bib.irb.hr/datoteka/561420.bajo-primorac.pdf [13.7.2017.].

Bajo,A., Primorac, M., Hanich, M. (2016) Restrukturiranje i privatizacija brodogradilišta u Hrvatskoj. Fiscus, 2:1-24.

Bazina, B. (2016) Uloga brodogradnje u gospodarstvu Republike Hrvatske s posebnim osvrtom na ishode procesa restrukturiranja.Zagreb: Faculty of Business and Economics, University of Zagreb [online]. Available at: https://urn.nsk.hr/urn:nbn:hr:148:647288 [15.6.2017.].

Bendeković, J., Vuletić, D. (2011) Financijska analiza poslovanja hrvatske brodograđevne industrije. Poslovna izvrsnost: znanstveni časopis za promicanje kulture kvalitete i poslovne izvrsnosti, 5 (1): 125-154.

DZS (2017) PC-Axis database of the Central Bureau of Statistics [online]. Available at: https://www. dzs.hr/App/PXWeb/PXWebHrv/Menu.aspx?px_db=Robna\%20razmjena\%20s\%20inozemstvom\&px_language $=h r \& r x i d=6 f 67 d b c f-a 5 d 4-4 e 56-99 a 5-2 f 6 c e 1414 e e 1$ [1.8.2017.].

European Council (2017) Exports Credit Group [online].Available at: http://www.consilium.europa.eu/en/ council -eu/ preparatory-bodies/exports-credit-group/ [22.6.2017.].

HBOR (2013) Prijedlog za odobrenje uvođenja poslovne promjene usklađenja poslovanja HBOR-a kao državne izvozno-kreditne agencije sa smjernicama OECD-a. HBOR's internal document. Zagreb: HBOR.

HBOR (2014) Informacija o mogućnostima i ograničenjima HBOR-a u praćenju brodogradnje i brodarstva kroz poslove osiguranja izvoza u ime i za račun Republike Hrvatske. HBOR's internal document. Zagreb: HBOR.

HBOR (2017a) Izvješće o poslovima osiguranja izvoza u ime i za račun Republike Hrvatske za razdoblje od 01.01. do 31.12.2016. HBOR's internal report.Zagreb: HBOR.

HBOR (2017b) Izvještaj o stanju portfelja po poslovima osiguranja izvoza na dan 31.12.2016. HBOR's internal report. Zagreb: HBOR.

HBOR (2017c) Godišnji financijski izvještaji za 2016. godinu. Zagreb: HBOR, p. 25 [online] Available at: https://www.hbor.hr/wp-content/uploads/2017/05/Godi\%C5\%A1nji-financijski-izvje\%C5\%A1taji-za-2016. godinu.pdf [19.6.2017.].

HBOR (2017d) Osiguranje kredita dobavljača. HBOR official web page [online].Available at: https://www. hbor.hr/ osiguranje-kredita-dobavljaca/ [15.6.2017.].

HBOR (2017e) Osiguranje činidbenih izvoznih garancija. HBOR official web page [online]. Available at: 
Sopta, M., Šola, L.

Managerial aspect of shipbuilding through HBOR export credit insurance operations https://www.hbor.hr/osiguranje-cinidbenih-bankarskih-garancija/ [15.6.2017.].

HBOR (2017f) Program osiguranja činidbenih bankarskih garancija izdanih radi zaključenja ili izvršenja izvoznog ugovora. Hrvatski izvoznici [online]. Available at: https://www.hrvatski-izvoznici.hr/Cms_Data/ Contents/hiz/Folders/dokumenti/ contents/36X2E4LYE5M5YC46/info---osiguranje--inidbenih-bankarskih-garancija-pdf [15.6.2017.].

HBOR (2017g) Poslovi izvozno-kreditnog osiguranja HBOR-a u ime i za račun RH, HBOR's internal report. Zagreb: HBOR.

Hrvatska brodogradnja - Jadranbrod (2017a) Svjetsko brodograđevno tržište - srpanj 2017.Zagreb: HBJ d.d., p 1-2 [online]. Available at: http://hb.hr/wp-content/uploads/2017/08/HBj-Svjetsko-trziste-2017-07. pdf [12.6.2017.].

Hrvatska brodogradnja - Jadranbrod (2017b) Knjiga narudžbi.Zagreb: HBJ [online]. Available at: http:// hb.hr/wp-content/uploads/2016/12/ob-web.pdf [15.6.2017.].

Kersan-Škabić, I. (2009) Brodogradnja u Europskoj uniji i Hrvatskoj, realnost i izazovi. Ekonomska misao i praksa, 2: 373-396.

Narodne novine (2009) Odluka Vlade Republike Hrvatske o objavljivanju pravila o državnoj potpori u obliku jamstava.Zagreb: Narodne novine d.d. [online].Available at: http://narodne-novine.nn.hr/clanci/sluzbeni/ 20090339 882.html [22.6.2017.].

OECD (2017a) About the OECD [online] Available at: http://www.oecd.org/about/ [June 22, 2017].

OECD (2017b) The Arrangement on Export Credits [online].Available at: http://www.oecd.org/tad/xcred/ arrangement.htm [June 22, 2017].

OECD (2017c) The Export Credits Arrangement text [online] Available at: http://www.oecd.org/tad/ xcred/theexportcreditsarrangementtext.htm [June 22, 2017].

OECD (2017d) Arrangement on Officially Supported Export Credits [online]. Available at: http:// www.oecd.org/officialdocuments/publicdisplaydocumentpdf/?doclanguage=en \&cote=tad/pg(2017)1 [22.6.2017.].

Perić Hadžić, A. (2013) Restrukturiranje hrvatske brodogradnje u kontekstu pristupanja Europskoj Uniji. Pomorski zbornik, 47-48 (1.): 121-132.

Rupčić, N. (2016) Upravljačka ekonomika Teorija i praksa. Rijeka: Faculty of Economics, University of Rijeka [online].Available at: https://www.efri.uniri.hr/sites/efri.uniri.hr/files/cr-collections/2/rupcicnatasa-upravljackaekonomika-teorijaipraksae-izdanje_locked.pdf [12.6.2017.].

Sokolić, D. (2008) Izgradnja konkurentske sposobnosti hrvatske brodogradnje. Zagreb: Faculty of Business and Economics, University of Zagreb [online].Available at: https://bib.irb.hr/datoteka/375915.lzgradnja_konkurentske_sposobnosti_hrvatske_brodogradnje.pdf [12.6.2017.].

The Publications Office of the European Union (2016) Uredba (EU) br. 1233/2011 Europskog parlamenta i Vijeća od 16. studenoga 2011. o primjeni određenih smjernica na području službeno podupiranih izvoznih kredita. Luxembourg: The Publications Office of the European Union [online]. Available at: https:// publications.europa.eu/hr/publication-detail/-/publication/e1c17790-f4f0-49be-b6e6-e6f9864f2438/language-hr [22.6.2017.].

Vukojević, Z. (2015) Uloga Hrvatske banke za obnovu i razvitak u kreditiranju gospodarstva Republike Hrvatske.Zagreb: RRiF Visoka škola za financijski menadžment [online].Available at: https://zir.nsk.hr/islandora/object/rvs:21 [15.6.2017.].

Žužul,V. (2016) Razvoj i buduće perspektive hrvatske brodogradnje.Zagreb: Faculty of Business and Economics, University of Zagreb [online].Available at: https:/urn.nsk.hr/urn:nbn:hr:148:222605 [13.6.2017.]. 